\title{
Legal Review on Online Ojek Related to Law No three the Year 2003 Concerning Manpower and Protection Law
}

\author{
Andi Nur Hidayah ${ }^{1}$, Faisal Santiago ${ }^{2}$ \\ \{andinurhidayah1@gmail.com¹, faisalsantiago@borobudur.ac.id² \\ Universitas Borobudur, Jakarta, Indonesia ${ }^{1,2}$
}

\begin{abstract}
Ojek is a cheap means of transportation used by the people, and the existence of Ojeks is in all corners of cities in Indonesia. The presence of Ojeks in the capital city is very much needed as public transportation that is cheap, fast, and simple because it uses motorbikes. The various conveniences and conveniences offered are an alternative to existing transportation problems, one of the advantages is that because they only have cellphones or gadgets and applications, consumers can order comfortable transportation with relatively much cheaper costs.
\end{abstract}

Keywords: Ojek Online; Work Relationship; Protection Consumer Law

\section{Introduction}

Transportation is a very significant aspect of the Indonesian personal minds. Recognizing the significance of road transport, vehicular and street transport should be organized in an integrated and capable national transportation system to recognize the availability of transportation services that are orderly, comfortable, fast, smooth, and low cost transportation services based on the level of traffic needs [1]. Globalization, which is currently taking place in all countries, including Indonesia, has affected many elements of people's lives, including culture, economy, and education. Increased migration or movement of people from one place to another, often fast, is one of the repercussions of globalization [2]. This transfer occurs and is required not only by persons, but also by commodities and services [3].

The characteristics of the type of use and people's mode of transportation can be divided into private vehicles and public transportation. Vehicle private vehicle is a vehicle operated only for people who own the vehicle. Public transportation is a vehicle provided for use by the public for a fee [4]. Rental cars and regular public transportation are the two types of public vehicles (transit). The motorcycle mode is included in the classification of private car types (private cars). Public transportation provides a diverse range of transportation options with varying degrees of service, convenience, and costs from one mode of transportation to the next. Motorized and non-motorized vehicles are used in public transportation. People who live or work in Jakarta or other big cities in Indonesia are no strangers to the rise of motorcycle taxis whose services are based on mobile applications. 
The growth of the online-based motorcycle taxi business is followed by increasing public interest, as evidenced by the continued increase in the number of downloaders of the application. Many news reports raise the story of online motorcycle taxi drivers from an economic point of view, making people flock to register themselves as motorcycle taxi drivers. Motorcycles are included in the type of private vehicle but are also used as public transportation to transport people and goods at an agreed fee. Transportation is divided into 2 (two) types, namely conventional motorcycle taxis and online motorcycle taxis. The convenience facilities provided by online motorcycle taxi services will undoubtedly satisfy passengers or consumers as users of online motorcycle taxi services.

Currently, the regulation for online transportation activities based on application technology is Minister of Transportation Regulation No. 32 of 2016 concerning the Organization of the Transportation of People with Public Motorized Vehicles Not on the Route. The type of service, operation, operation of public transportation with information technology-based applications, public transportation monitoring, community involvement, and administrative sanctions are all covered by this rule. The Ministerial Regulation is regarded acceptable for the time being, but it will need to be updated in the future to keep up with rapid technological advancements. On the other side, there is a demand for low-cost, simple, and convenient modes of transportation. law number 22 of 2009 concerning Road Traffic and Transportation needs to be improved because several essential things must be clear, for example, the issue of Foreign Legal Entities and their share ownership including licensing and cooperation agreements between the parties (service companies, transportation providers and drivers, consumers) and several aspects other laws, such as the issue of the protection of the service user.

In addition, the existence of a service provider company that must comply with several obligations as stipulated in the Ministerial Regulation mentioned above (effective from 1 September 2016) is essential for supervision because it is related to consumer convenience. This supervision issue is often neglected so that the rights of consumers are also ignored. The preparation of comprehensive regulations regarding transportation based on application technology is essential, as has been done by many other countries that accommodate this type of transportation, such as Australia, Bulgaria, Canada, Germany, the Philippines, and others. This is in line with the views of transportation experts who say that technology-based transportation applications should be accommodated by perfecting the existing laws and regulations, namely Law number 22 of 2009 concerning Road Traffic and Transportation.

\section{Methodology}

The research method used is normative juridical (legal research). The juridical research method is legal research that utilizes secondary data sources. Secondary data is obtained from library data to solve problems, analyze, investigate or research a field of science that is carried out to get facts with the intention that the information that has been collected will be relevant to the problem being investigated so that the data is through thinking by linking the literatureexisting literature and a conclusion can be obtained that is believed to be accurate and can be held accountable for the result 


\section{Results and Discussion}

\subsection{General Rental Transportation and Special Rental Transportation}

The Ministry of transportation made changes to the definition of Rental Transportation. Rental transportation was previously defined as door-to-door transportation services provided by renting a vehicle with or without a driver. In this regulation, the term Rental Transport is revised to "door-to-door transportation provided employing a rental vehicle." After that, the Ministry of Transportation has broken it down into two, namely General Rent Transport and Special Lease Transport. Services such as Uber, Grab, and Go-Car, enter the Special Hire Transport, and they will get a special sticker for easy identification.

Public Rental Transportation: door-to-door transportation services provided by renting a vehicle with or without a driver through wholesale based on a specific period. Special Rental Transportation: door-to-door transportation services whose operational areas are in urban areas, provided by renting a vehicle with a driver and order using an information technologybased application. In Special Lease Transportation, the tariff is stated on an information technology-based application and follows the agreement between the service user and the transportation company. However, the Ministry of Transportation plans to set an upper and lower limit on this fare to create a balance with other modes of public transportation. The determination of the upper and lower foods will be decided by the local government (Pemda) after accommodating the aspirations of city transportation entrepreneurs (angkot) and online transportation partners.

According to local needs, the number of vehicles for online transportation partners will also be limited. The regional government will determine the capacity of this particular rental car and can be evaluated periodically every year. Previously, Vehicle Number Certificates (STNK) provisions for online transportation driver partners were required on behalf of the company. It is now revised to STNK on behalf of a legal entity. For STNK that is still in the name of an individual, it is still allowed to operate and is valid until its expiration date. Many suggestions from online transportation driver-partners can use a car with a cylinder capacity of $1,000 \mathrm{ccs}$, which has finally been realized. In the old rules, the Ministry of Transportation stipulates that the minimum specifications for vehicles used for rental transportation are 1,200 cc cylinders. Meanwhile, the Ministry of Transportation stipulates a minimum car vehicle with a cylinder of $1300 \mathrm{CC}$ for public rental transportation. Kir is still required to be carried out by the rental car owner, and proof of passing the periodic test will be carried out by giving a plate embossed with a test number. The obligation to have a place to store vehicles has been revised to a storage area that can accommodate the number of cars owned.

This is the access provided by companies providing information Technology-based applications to the government to monitor the operation of transportation services so that they can supervise and develop transportation operations. (a) Transport operators not on routes that use Information Technology-based applications are obligated to comply with the provisions in the field of public transportation business (including the obligation to have a license and be a legal entity). (b) Transportation operators not on routes that use IT-based applications that do not fulfill these obligations are required to stop the operation of motorized vehicles and their applications. (c) he IT-based application provider company must provide dashboard application access to the transport operator not on the route and the Director-General as the vehicle controller and driver, including administrative completeness. (d) The dashboard application contains at least: - company profiles that provide internet-based application services; - give access to operational service monitoring; - data on all cooperating public 
transport companies; - data on all vehicles and drivers; - customer service in the form of telephone, email, and office address for Information technology-based application providers.

It takes time and money to realize a quality transportation system. It is not only the Government and related agencies responsible for improving Indonesia's public transportation system. The entire community must also be able to play an active role in assisting the government in building and running Indonesia's current public transportation system.

\subsection{Mechanism doing Online Application-Based Transportation Services}

The operation of an electronic system is defined as the usage of an electronic system by state administrators, people, businesses, and the general public, according to Article 1 paragraph 6 of the Electronic Information and Transaction Law. Electronic systems as a liaison between car users and service users, which is a basic aspect of the birth of online application-based transportation services, are provided by the supplier of online software transport companies. As an application provider, you have a crucial role in an online application-based transportation system's success because application service providers are a liaison between supply and demand, namely application providers or application companies, drivers, and users of online application-based transportation services. The online applicationbased transportation service provider as the operator of the electronic system has responsibilities as stipulated in article 15 of Law Number 11 of 2008 as amended by Law Number 19 of 2016 concerning Electronic Information and Transactions

a. Every operator of the electronic system is responsible for the electronic system's correct operation and reliability.

b. The electronic system operator is in charge of the electronic system's operation. The rules of paragraph (2) are not applicable if it can be demonstrated that the user of the electronic system was subjected to coercive conditions, errors, or negligence.

\subsection{Working Relationships Between Online Ojek Drivers and Companies as a Form of Civil Law}

According to Article 1 point 3 of Law Number 13 of 2003 Concerning Manpower, a worker or laborer is defined as "someone who works in exchange for pay or other types of remuneration". Regarding the purpose of a worker, to be called a worker according to Law Number 13 of 2003 concerning Manpower, one must meet the following requirements. There must be a work agreement, a formal working relationship, and work for the company. Meanwhile, the definition of Manpower according to Article 1 number 2 of Law Number 13 of 2003 concerning Manpower states that: A human resource is every person, both male or female, who can do work to produce goods and or services either to meet his own needs or to fulfill his own needs. for society

Based on the description above, the definition of labor has a broader meaning than the understanding of workers because labor includes everyone, both currently and those who will do work, while workers have limitations on everyone who is doing work, especially in employment relationships. workers, the legal relationship with the employer is civil, that is, made between parties who have a civil position. A Work Agreement is an agreement between a worker or laborer and an entrepreneur or employer that specifies the working conditions, rights, and obligations of the parties, according to Section 1 No 14 of Act Number 13 of 2003 regulating Manpower. 
The parties involved in the implementation of online motorcycle taxi transportation have relationships that are bound by an online transportation agreement. The meaning of the agreement can refer to the opinion of legal scholars. According to Subekti, "An agreement" is defined as "an event in which one person makes a commitment to another or where two persons promise to carry out a task together." Another legal scholar believes that namely Wirjono Prodjodikoro, an agreement is "a legal relationship regarding property between two parties, in which one party promises or is deemed to have promised to do something or not to do something, while the other party has the right to demand the implementation of that promise.

Electronic transactions between online transportation companies and consumers or service users begin when the consumer or user downloads the transportation service application by stating the choice to agree to the terms and conditions set by the online transportation company. The validity of the engagement is a consequence of the choice to agree to the terms and conditions provisions contained in the application of online transportation services. The agreement between the parties made electronically is an electronic document that can be used as legal evidence (see Article 5 paragraph (1) of the Electronic Information and Transaction Law). Article 1320 of the Indonesian Civil Code can be used legally in a work agreement. There is an agreement between the parties, meaning that the worker or laborer and the entrepreneur in a work agreement must have free will to bind themselves in the contract. In this case, the driver (driver) has agreed to join as a worker (partner) at the company, and the driver (driver) decides to share the proceeds by $20 \%$ to the company and $80 \%$ to the driver (driver).

In this case, the driver (driver) has agreed to join as a worker (partner) at the company. The driver (driver) decides to share the proceeds by $20 \%$ to the company and $80 \%$ to the driver (driver). Proficient in carrying out legal actions, meaning the ability or ability to carry out lawful activities for workers or laborers or entrepreneurs, so seen from that to become drivers or workers, the company must be capable people, such as those aged 18 years. The existence of an object of the agreement, in the agreement between the driver (driver) and the company that the thing of the agreement between the driver (driver) of the company is the driver (driver) providing services in terms of delivering passengers, as well as providing goods, following the agreement in the agreement. Halal or legal, meaning that the agreement made by each party must not conflict with the law, public order, and decency

Subjects in the employment agreement can carry out legal actions or enter into contracts. A person's ability is usually associated with a person's maturity limit. In labor law, an adult is 18 (eighteen) years old. The agreement between the driver (driver) and the Ojek Online company is a partnership agreement. One of the partnership agreement forms is a profit-sharing agreement between the parties. On the other hand, the reason why it is called a partnership agreement between the driver (driver) and the Ojek Online company, because the agreement is the company only as an intermediary to provide passengers or handle passengers who enter the Android smartphone application that the ojek driver uses to carry out his work, namely delivering passengers or deliver well.

This is if it is considered in a legal relationship or employment relationship, where doing work that was born based on a partnership based on the principles in the work agreement, one of which is the principle of freedom of contract, the focus of consensus, and following the provisions of Article 1320 of the Indonesian Civil Code. Legal relations appear because of an agreement involving two parties, namely the employer and the party who will carry out the work following the agreement hold Article 1 Number 15 of Law Number 13 of 2003 concerning Manpower it is stated that: Employment relationship is a relationship between an 
entrepreneur and a worker or laborer based on a work agreement, which has elements of work, wages, and orders.

The elements of the working relationship in question include: what is meant by the work component is something that the recipient of the work must do. The existence of an element under the order makes the recipient of the job very dependent on the order of the employer or company. Wage is a reward for the work done by the worker as the recipient of the work. What is meant by the element of work is something that the recipient of the work must do. The existence of a component under the order makes the recipient of the job very dependent on the order of the employer or company. Wage is a reward for the work done by the worker as the recipient of the work. While there is an element of time, in this case, there is a time to do the job in question is the length of time carried out by workers who do the work given by the employer.

Review at the problems that exist in online motorcycle taxi workers or drivers who think that he is one of the employees of the Ojek Online company, according to too the writer this, when viewed from the elements of the working relationship, namely: the aspect of work, the component of wages and the component of orders. . However, in reality, online motorcycle taxi drivers do not fulfill the elements of wages and charges, because orders to online motorcycle taxi drivers are given directly by customers or consumers, and these orders are not given directly by employers as employers, while the wage element is in the working relationship between drivers. Online ojek online ojek drivers get wages or rewards from customers or consumers. The wages that the employer should give to the employer.

\subsection{Legal protection for Consumers as Users of Online Motorcycle Taxi Services Based on Law no. 8 of 1999 concerning Consumer Protection}

As for the obligations of business actors as regulated in the provisions of Article 7 of the Consumer Protection Law based on the requirements of the Consumer Protection Act, basically, in protecting consumers as users of online motorcycle taxi transportation services, business actors as online motorcycle taxi transportation service providers must protect their consumers in terms of security, safety and comfort in using the services provided. The following will describe things about the protection that must be given to online motorcycle taxi consumers by business actors.

a. In terms of online motorcycle taxi transportation security. The security aspect of online motorcycle taxi transportation includes the vehicle's identity and the identity of the online motorcycle taxi driver. Online motorcycle taxi service users (consumers) who use specific online motorcycle taxi transportation applications when placing an order and the approval of the price as stated in the online motorcycle taxi transportation application, a complete identity will appear in the application related to the driver's identity and the driver's vehicle identity. Services and the use of attributes by the driver so that service users are not worried about online motorcycle taxi transportation insecurity.

b. In terms of the safety of online motorcycle taxi transportation. Online motorcycle taxi service providers in carrying out the transportation of goods and people from one place to a particular place must be safe, meaning that it does not cause harm to the service user. The safety of online motorcycle taxi transportation includes the standard of operating online motorcycle taxi services, vehicle facilities, and infrastructure that support the implementation of online transportation and the driver's condition in providing services.

c. In terms of the convenience of online motorcycle taxi transportation. Online motorcycle taxi transportation currently developing in major cities in Indonesia has provided comfort 
that can be felt by online motorcycle taxi service users (consumers). In terms of punctuality and online motorcycle taxi service, users (consumers) also get affordable rates and other advantages of online motorcycle taxi transportation, namely the services provided not only for the transport of people (traveling services) but also various services offered by each of them. Each online ojek transportation application company.

\section{Conclusion}

In practice, the working relationship between online motorcycle taxi drivers and the company as a form of civil relationship between the company and the driver is not included in the working relationship. The wages earned by the driver are gifts from passengers. Under these conditions, the elements of a working relationship between the company and the driver are not fulfilled, but only a partnership relationship. Suppose the consumer feels that the quantity and quality of the service is not appropriate. In that case, the consumer is entitled to receive reasonable compensation under Article 19 paragraph (1) and paragraph (2) of Law Number 8 of 1999 concerning Consumer Protection.

\section{References}

[1] T. Beierle, Public Participation in Environmental Decisions: An Evaluation Framework Using Social Goals. 1998.

[2] M. Rachmawati, M. I. Pratiwi, E. E. Supriyanto, F. J. Nugroho, and L. Mariana, "The University ' s Knowledge Management Strategy Towards a World-Class University," in 1st International Conference on Research in Social Sciences and Humanities, 2021, vol. 584, no. Scorch 2020, pp. 869-872.

[3] D. Kurniawan, A. Sutan, I. Mufandi, E. Supriyanto, and M. Rachmawati, "Social Media Used to Spread Vaccination Program: Case of Indonesia Vaccination Covid-19 Policy," 2021, doi: 10.4108/eai.6-3-2021.2306469.

[4] S. Spengler, "Educators' Perceptions of a 21st Century Digital Literacy Framework," Walden Univ., p. 200, 2015, [Online]. Available: https://search.proquest.com/docview/1680843631 accountid=35516\%0Ahttp://uwiprimoalma prod.hosted.exlibrisgroup.com/openurl/MIL/mil_services_page?url_ver=Z39.882004\&rft_val_fmt=info:ofi/fmt:kev:mtx:dissertation\&genre=dissertations $+\% 26+$ theses \&sid=ProQ:Pro. 